
\section{$C_{\text {citus }}$}

${ }^{1}$ Department of Plastic Reconstructive and Aesthetic Surgery, Villa Salaria Clinic, Rome, Italy

${ }^{2}$ Department of Plastic and Reconstructive Surgery, University of Rome 'Tor Vergata', Rome, Italy

\section{Correspondence to} Dr Davide Lazzeri, Plastic Reconstructive and Aesthetic Surgery, Villa Salaria Clinic, via Filippo Antonio Gualterio, 127 Rome 00139, Italy: davidelazzeri@gmail.com

Received 20 December 2015 Revised 27 January 2016 Accepted 29 January 2016 Published Online First 22 February 2016

\title{
Pectus excavatum in paintings by Jusepe de Ribera (1591-1652)
}

\author{
Davide Lazzeri, ${ }^{1}$ Fabio Nicoli ${ }^{1,2}$
}

The intensity of realism pursued by Caravaggio in contrast with Mannerism was amplified by his followers ("Caravaggisti"); these included the Spanish painter, Jusepe de Ribera, with his tenebristic style as classified by the early biographers. ${ }^{1}$ Indeed, de Ribera mastered the Caraveggesque chiaroscuro and gained widespread popularity as a result of his lifelike naturalism, becoming the most influential Spanish Baroque painter. He depicted dramatic and sinister scenes of tortured saints with faces contorted in pain, mutilated and ageing bodies adorned with sagging flesh, gruesome martyrdoms and societal outcasts. ${ }^{1}$

The great realism of de Ribera is shown in masterpieces in which anatomical abnormalities or medical diseases afflicted the sitters. Such works included The Clubfoot (arthrogryposis), The Bearded Woman (endocrinological disease), The Allegory of Touch (blindness) and the drawings of The Grotesque Heads of Men (thyroid goitre). Interestingly, we have observed that in three further portraits, de Ribera depicted Saint Jerome and Saint Onophrius with chest deformity resembling pectus excavatum (figures 1-3). He rendered the saints unkempt, half naked and wearing poor cloths. The cadaverous habitus, dirty fingernails, hollowed cheeks and flesh sagging from their

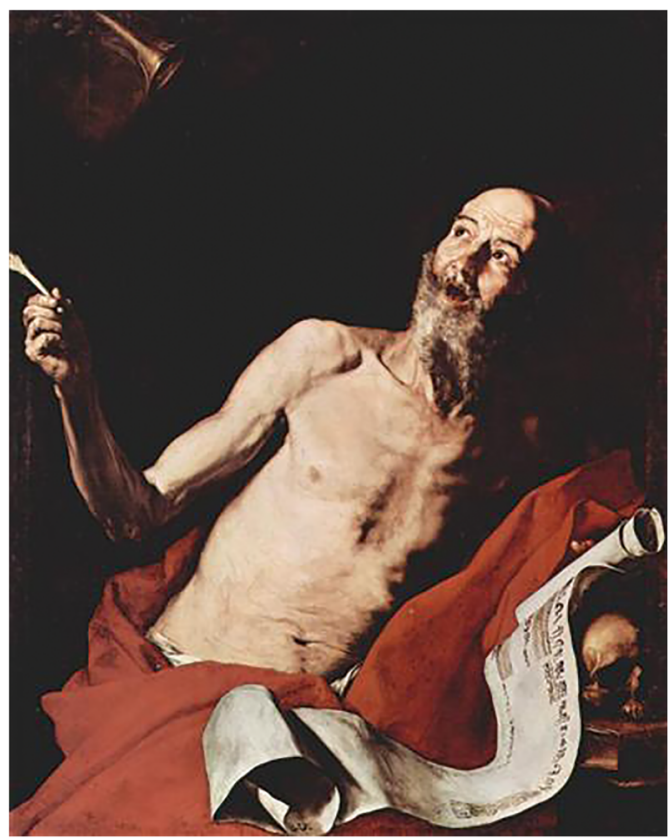

Figure 1 St Jerome and the Trumpet of Doom (1637), by Jusepe De Ribera, oil on canvas (from the Galleria Doria Pamphilj, Rome, Italy). emaciated frames completes the dramatically realistic portraits.

The reasons for such depictions could be multiple and are worthy of discussion. It seems unlikely that the first medical description of pectus excavatum and its physiological consequences provided by Schenck and Bauhin at the end of the 16th century, a few decades before de Ribera's depictions, exerted a great deal of influence. ${ }^{2}$ De Ribera was a skilled draftsman and printmaker, leaving hundreds of drawings; therefore, because of his high reputation, it seems unrealistic that the artists inadvertently depicted the chest deformity while unaware of the underlying abnormal condition, especially as such mistakes would have been adjusted in the final piece. From the 14th century onwards, the depiction of physical deformity was used as a symbolic celebration of martyrs in the cult of some saints. ${ }^{3}$ Someone could argue that de Ribera may have embraced this tendency and may have attempted to highlight the martyrdom and the sufferance of both saints with the inclusion of pectus excavatum in order to elicit feelings of empathy, humility and piety. This is unlikely because the analyses of the several half-length images of saints that he portrayed did not reveal a similar pathology, and also because neither Saint

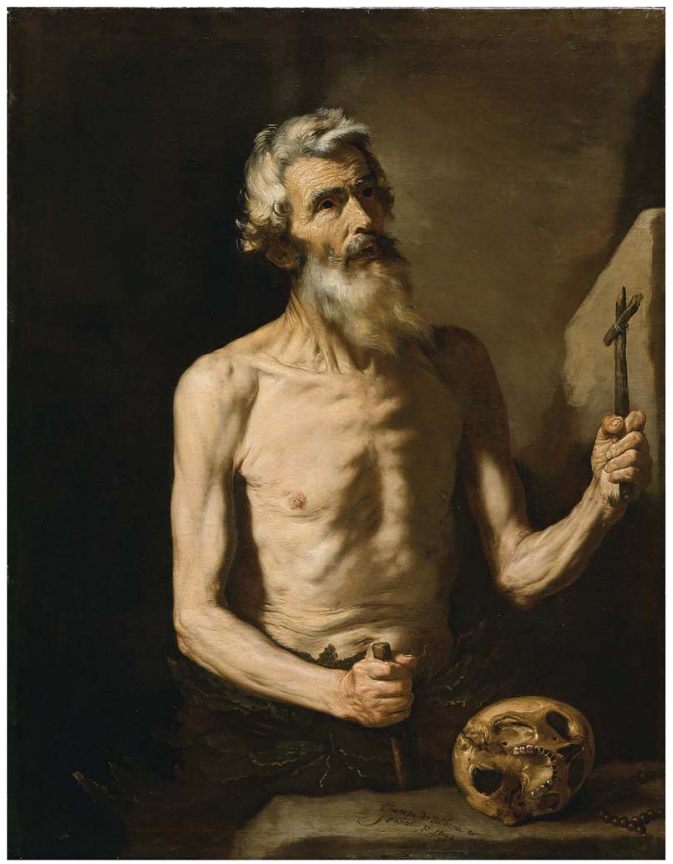

Figure 2 Saint Onophrius (1642), by Jusepe De Ribera, oil on canvas (from the Museum of Fine Arts, Boston, Massachusetts, USA). 


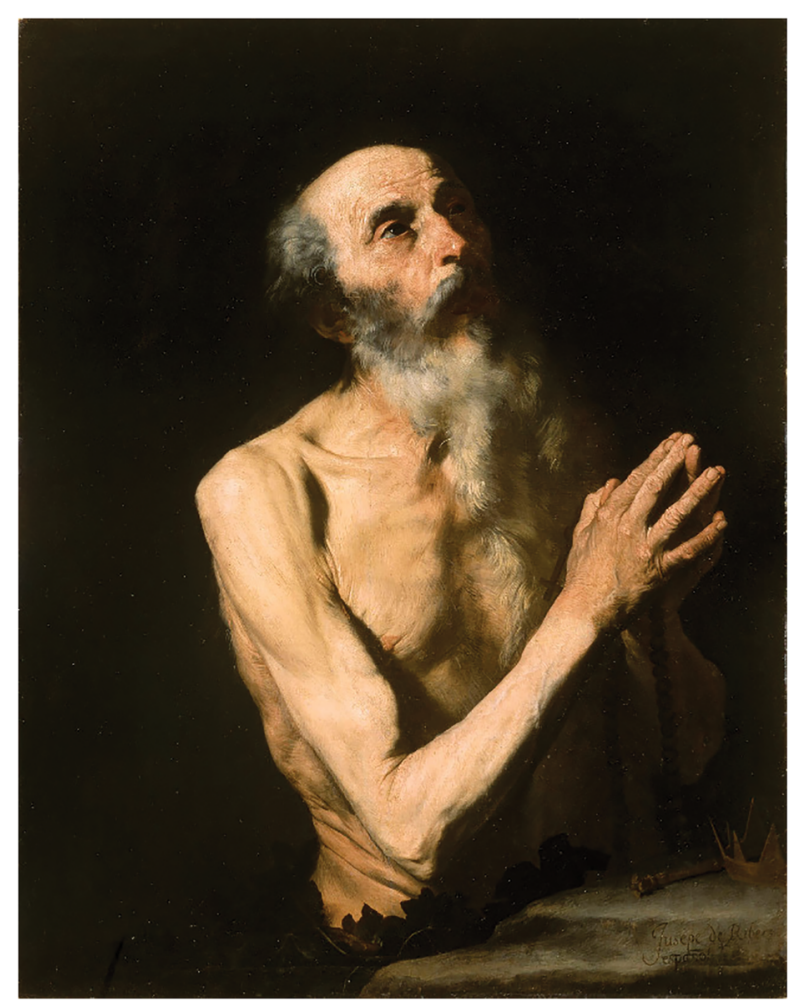

Figure 3 Saint Onophrius (1625-1629), by Jusepe De Ribera, oil on canvas (from the National Gallery, Dublin, Ireland).

Jerome nor Saint Onophrius endured martyrdom during their life. Furthermore, we cannot entirely reject the claim that the artist might have been aware of Leonardo's first anatomical drawings of pectus excavatum. ${ }^{2}$ It is reasonable to debate whether the saints herein referenced had true pectus excavatum or simply rather cadaverous physiques. However, de Ribera portrayed further saints (Andrew, Bartholomew and Paul) and depicted Jerome and Onophrius in further portraits with a clear cadaverous habitus but without sign of chest deformity. This is meaningful about the intention of de Ribera to include such deformity in the portraits of this investigation (figures 1-3).

The most suitable theory is that the Spanish painter sought out models who were elderly and emaciated and had mild chest deformity that enabled the painter to depict the contrast of light and shade on the chest wall. De Ribera could combine his chiaroscuro tenebristic style with the tendency towards a great realism in the representation of the sitters, which reflected the increased anatomical accuracy and knowledge developed during that period. Previous dramatic depictions of anatomical abnormalities and medical diseases by de Ribera may strengthen our hypothesis.

In conclusion, whether the eventual chest deformity was deliberately introduced by the artist or the models were actually affected is speculative, but both explanation underlines the fascination of de Ribera in the abnormal and macabre and in the use of strong tenebristic contrasts between light and dark.

Competing interests None declared.

Provenance and peer review Not commissioned; externally peer reviewed.

\section{REFERENCES}

1 Pérez Sànchez AE, Spinosa N. Jusepe De Ribera. The Metropolitan Museum of Art. New York: Abrams NH, Inc., 1992:12-5.

2 Ashrafian $\mathrm{H}$. Leonardo da Vinci and the first portrayal of pectus excavatum. Thorax 2013;68:1081.

3 Hope C. Altarpieces and the requirements of patrons. In: Verdon T, Henderson J, eds. Christianity and the Renaissance: Image and Religious Imagination in the Quattrocento. Syracuse, NY: Syracuse University Press, 1990:535-71 (p. 554). 